REGARDS

SUR LECONOMIE ALLEMANDE

BULLETIN ECONOMIQUE DU CIRAC
Regards sur l'économie allemande

Bulletin économique du CIRAC

108 | 2013

Varia

\title{
Patrimoine : les Français plus riches que les
}

Allemands

\section{Isabelle Bourgeois}

\section{OpenEdition}

1 Journals

Édition électronique

URL : http://journals.openedition.org/rea/4531

DOI : 10.4000/rea.4531

ISSN : 1965-0787

Éditeur

CIRAC

\section{Édition imprimée}

Date de publication : 2 avril 2013

Pagination : 39

ISSN : 1156-8992

\section{Référence électronique}

Isabelle Bourgeois, "Patrimoine : les Français plus riches que les Allemands », Regards sur l'économie allemande [En ligne], 108 | avril 2013, mis en ligne le 04 avril 2013, consulté le 15 septembre 2020. URL : http://journals.openedition.org/rea/4531

Ce document a été généré automatiquement le 15 septembre 2020.

(c) CIRAC 


\title{
Patrimoine : les Français plus riches que les Allemands
}

\author{
Isabelle Bourgeois
}

1 Les Allemands ont moins de patrimoine que les Européens du sud. Et il est très inégalement réparti: les $10 \%$ des ménages les plus riches possèdent $59,2 \%$ du patrimoine net total (données publiées le 21 mars par la Bundesbank). Voilà de quoi alimenter les controverses européennes comme les débats électoraux en Allemagne l'amalgame entre niveau de vie ou revenus et patrimoine est vite fait. Or ces inégalités s'expliquent : ce patrimoine est souvent, par exemple, le capital d'une PME (société de personnes); son patron n'est pas pour autant 'riche' en ce qui concerne son revenu. Quant à la disparité avec les autres Etats de l'UE, elle s'explique entre autres par les ruptures historiques qui se sont succédé en Allemagne et qui ont détruit beaucoup de patrimoine, alors qu'en Europe du Sud et en France, il a pu se construire dans la continuité : inflations de 1923 et 1929, expropriations sous le IIIe Reich, puis en RDA (ce dernier point explique le différentiel actuel). Une autre « affaire » à suivre ? (IB)

Patrimoine net $\left.{ }^{\star}\right)$ des ménages allemands en comparaison européenne (état : fin 2010)

\begin{tabular}{|l|l|l|l|l|l|}
\hline & Allemagne & France & Espagne & Italie & Autriche \\
\hline Patrimoine net moyen (en $€)$ & 195200 & 229300 & 285800 & & 265000 \\
\hline & $\begin{array}{l}\text { Ouest: 230 240/ Est: } \\
67500\end{array}$ & & & & \\
\hline Patrimoine net médian (en $€)$ & 51400 & 113500 & 178300 & 163900 & 76400 \\
\hline & $\begin{array}{l}\text { Ouest: } 78900 / \text { Est: } \\
21400\end{array}$ & $57,9 \%$ & $82,7 \%$ & $68,4 \%$ & $47,7 \%$ \\
\hline $\begin{array}{l}\text { Propriétaires de leur logement } \\
\text { (en \%) }\end{array}$ & $44,2 \%$ & & & \\
\hline
\end{tabular}




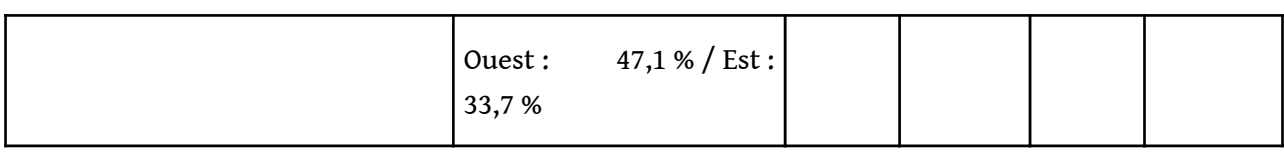

Source des données : Deutsche Bundesbank, Private Haushalte und ihre Finanzen (PHF), Pressegespräch zu den Ergebnissen der Panelstudie, 21-03-2013. *) Patrimoine immobilier, financier + couverture sociale - crédits et hypothèques. NB : Enquête représentative (Allemagne: 3565 ménages) menée de septembre 2010 à juin 2011 dans le cadre du Household Finance and Consumption Survey (HFCS) du réseau des banques centrales de la zone Euro.

INDEX

Mots-clés : revenu, patrimoine, niveau de vie, logement, comparaison européenne, France, Espagne, Italie, Autriche 